\title{
7 Delimiting instruments from instrument-like participants
}

In the introduction, it was explained that in many languages the marking typically employed for instruments has a wide range of other functions. Some of these functions are clearly adverbial in nature and are not an object of the present study. So far, I have explored the prototypical cases of instruments and the related concept of implements. However, there are several cases where a certain constituent superficially resembles an instrument, such as in (1).

(1) a. John ran to the store with the hammer.

b. The woman with the book left the room.

c. Jan ren-de naar de winkel met de Jan run-PST.3SG to DEF store with DEF

hamer.

hammer (Dutch)

d. De vrouw met het boek verliet de kamer. DEF woman with DEF book leave $P S T .3 S G$ DEF room

The status of such constituents is far from clear. This chapter is intended to explore their properties and how they can be captured in RRG. Reference is also sometimes made to human instruments. I treat these as causees and I will explore their status in relation to instruments. By delineating such concepts from instruments and implements, I aim at providing a sharper definition of the instrument notion. 


\subsection{Causees}

The intermediate effector position is not restricted to inanimates (or lesser animates) only. In fact, causees can be considered as a kind of human instrument and there appear to be great parallels between them: The causee is acted upon to perform an activity similar to an instrument. Neither causees nor instruments are 'primary causers', to use Schlesinger's (1989: 194) terms, but entities caused to do something. It then stands to reason that examples with causees and instruments should pass the same causal paraphrase testing that I have been applying thus far. Consider $(3 a-3 c)$ compared to $(3 \mathrm{~d}-3 \mathrm{f})$ :
a. Jean a
fait
couper le pain à Marie. Jean AUX.3SG make.PTCP cut DEF bread to Marie 'Jean made Marie cut the bread.' (French)
b. Jean a agit sur Marie, ce qui a Jean AUX.3SG act.PTCP on Marie REL AUX.3SG causé qu'elle coupe le pain. cause.PTCP that $=3$ SG.F cut.3SG DEF bread 'Jean acted on Mary, causing her to cut the bread.'
c. Marie a agit sur le pain, cequi Marie AUX.3SG act.PTCP on DEF bread REL a causé qu'il est coupé. AUX.3SG cause.PTCP that=3SG.M AUX.3SG cut.PTCP 'Mary acted on the bread, causing it to be cut.'
d. Jean a coupé le pain avec un couteau. Jean AUX.3SG cut.PTCP DEF bread with INDEF knife. 'Jean cut the bread with a knife.'
e. Jean a agit sur le couteau, cequi Jean AUX.3SG act.PTCP on DEF knife REL a causé qu'il coupe le pain. AUX.3SG cause.PTCP that=3SG.M cut.3SG DEF bread. 'Jean acted on the knife, causing it to cut the bread.' 
f. Le couteau a agit sur le pain, cequi DEF knife AUX.3SG act.PTCP on DEF bread REL a causé qu'il est coupé. AUX.3SG cause.PTCP that=3SG.M AUX.3SG cut.PTCP 'The knife acted on the bread, causing it to be cut.'

The logical structures for (3a) and (3d) will look very similar. They are given in (4).
a. $\quad\left[\mathbf{d o}^{\prime}(\right.$ Jean,,$\left.)\right]$ CAUSE $\left[\left[\right.\right.$ do’’ $^{\prime}$ (Marie, Ø)] CAUSE [BECOME

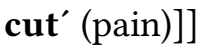
b $\quad\left[\mathbf{d o}^{\prime}(\right.$ Jean, $\left.\varnothing)\right]$ CAUSE $\left[\left[\mathbf{d o}^{\prime}(\right.\right.$ couteau, $\left.\varnothing)\right]$ CAUSE [BECOME cut' (pain)]]

If causees and instruments arguably occupy the same position in the logical structure, why and how do we distinguish between them? If they occupy the same position and pass the same tests, then would it not be simpler to treat them as the same category? One argument in favor of keeping these notions separate is that languages usually have different preferred linking strategies for them. In French, causees (under the scope of direct causation) prefer the dative marker $\dot{a}$ combined with a nuclear juncture, whereas instruments prefer the preposition avec. In English, instruments prefer the linking strategy with a with-PP, whereas causees prefer a (complex) construction with a causative verb. The example in (5d) is inadmissible because rock is too low on the actionality scale to be a realistic causee. As an instrument, it is incompatible with a typical expression of causees (make-construction). Consider English, German ((5e-5h)) and Dutch $((5 \mathrm{i}-5 \mathrm{l}))$ :
a. I had Bill break the window.
b. ?I broke the window with Bill. ${ }^{1}$
c. I broke the window with the rock.

1 This sentence is perfectly acceptable if it is interpreted as a comitative construction. As a causee construction, however, it is of questionable acceptability. The same holds for the German and Dutch equivalents in (5). 
d. "I made the rock break the window.

e. Ich ließ $\beta \quad$ Erich das Fenster einschlag-en. 1SG let\PST.1SG Erich DEF window bash in-INF

f. ?Ich schlug das Fenster mit Erich ein. 1SG bash in $\backslash$ PST.1SG DEF window with Erich VPR

g. Ich schlug das Fenster mit einem 1SG bash in\PST.1SG DEF window with INDEF Stein ein. rock VPR

h. ${ }^{*} I c h$ ließ $\beta$ einen Stein das Fenster 1SG let|PST.1SG INDEF rock DEF window einschlag-en. bash in-INF

i. Ik deed Erik het raam 1SG make $\mid$ PST.1SG Erik DEF window ingooi-en. throw in-INF

j. ?Ik gooi-de het raam in met Erik. ${ }^{2}$ 1SG throw-PST.1SG DEF window VPR with Erik

k. Ik gooi-de het raam in met een 1SG throw-PST.1SG DEF window VPR with INDEF steen.

rock

1. ${ }^{*} I k$ deed steen het raam 1SG makeไPST.1SG DEF rock DEF window ingooi-en.

throw in-INF

There are some arguments that can be realized with typical instrumentmarking, despite being a causee. Consider the following examples: (6c) is an LS corresponding to (6a). A paraphrase of (6a) is given in (6b).

2 The Dutch verb ingooien (literally: throw in) is the most direct equivalent of English break in this context. 
(6) a. The general captured the city with only a handful of soldiers. ${ }^{3}$

b. The general made the soldiers capture the city.

c. [do' (general, Ø)] CAUSE [[do' (soldiers, Ø)] CAUSE [BECOME captured' (city)]]

d. The soldiers captured the city.

In (6a) typical instrumental marking is employed for the causee. There is a good reason not to treat soldiers as an instrument, but as a real causee: If ISA were applied as in (6d), Holisky's principle would link it back to an LS with the argument as an agentive instigator. It is given in (7a). Further compare (7a) to $(7 b-7 c)$.
a. [do' (soldiers, Ø)] CAUSE [[do' $(\varnothing, \varnothing)]$ CAUSE [BECOME destroyed' (city)]]
b. The soldiers destroyed the city with a catapult.
c. [do' (soldiers, Ø)] CAUSE [[do' (catapult, Ø)] CAUSE [BECOME destroyed' (city)]]

The default interpretation of $(6 \mathrm{~d})$ is one where the soldiers themselves act as the instigator. The same applies to (5a) if one were to attempt ISA:
a. Bill broke the window.
b. [do' (Bill, Ø)] CAUSE [BECOME broken' (window)]

It was illustrated by the examples in (5) that human referents are not compatible with instrument-marking (in this function, see footnote 80) and inanimates are not compatible with causee-marking. However, the referent of soldiers is a group of humans. Groups and organizations are usually considered less animate than individual humans in most approaches to animacy. In my actionality scale, they rank as anthropomorphic entities on the animacy hierarchy (just like Bill, for instance), but they are lower in autonomy than individuals. In short, their position on the actionality scale is lower than that of Bill. This has a reflex in linking preferences in English. Soldiers allows for both the made-strategy and the with-strategy.

3 This sentence can also have a comitative reading. However, world knowledge of how military organizations operate makes this reading somewhat unlikely. 
Most referents are only compatible with one strategy but lower-ranking causees will typically allow for both. This is equally true for Dutch and German:
a. De generaal vernietig-de
de stad met
DEF general destroy-PST.3SG DEF city with de soldaten.
DEF soldiers (Dutch)
b. De generaal deed de soldaten de stad DEF general make $\mid P S T .3 S G$ DEF soldaten DEF city vernietig-en. destroy-INF
c. Der General zerstör-te die Stadt mit DEF general destroy-PST.3SG DEF city with den Soldaten.
DEF Soldiers (German)
$\begin{array}{llll}\text { d. Der General ließ } & \text { die Soldaten die } \\ \text { DEF general let } \text { PST.3SG } & \text { DEF soldiers DEF }\end{array}$ Stadt zerstör-en. city destroy-INF

It is clear from the examples discussed thus far that a typical causee occupies a higher position on the actionality scale than a typical instrument. However, it would be too simple to assume that the differences in actionality can provide a complete answer. There are cases where referents can be either an instrument or a causee (or be ambiguous).

(10) a. fohn broke the window with the dog. (by throwing the dog)

b. John had the dog break the window. (by ordering the dog)

c. The dog broke the window with a stick.

Again, $d$ go can be a real causee, as applying ISA to (10b) would rather link back to an LS with dog as instigator as evidenced by its instrument-taking potential ((10c)). The referent $d o g$ changes actionality status between (10a) and (10b). In (10a), dog refers to the dog's body as a physical object, rather 
than to the dog as a whole. In terms of actionality status, dog in (10a) is much lower on the scale than it is in (10b). Therefore, in (10a), it is an instrument as it is too low to be a realistic candidate for causeehood. This is parallel to more commonplace instruments and causees: Instruments like rock have to be manipulated more directly than referents like soldiers or Bill. The former requires physical handling on the part of the manipulator, whereas the latter do not due to their position on the actionality scale. Typical causees are much higher on the scale than typical instruments with only very few referents that can be conceptualized as both. This difference in actionality has repercussions for the type of causation that each is under the scope of (or can be). In chapter 5, I explored an expanded system of causal operators in RRG's logical structures and I suggested representing indirect causation with a different causal operator. Causees can be under the scope of direct or indirect causation, whereas instruments can only be under the scope of direct causation. To illustrate this difference, consider the French examples in (11). The LS in (11e) underlies both (11a) and (11c) and has the underspecified causal operator as introduced in chapter 5 .

a. Jean a fait couper le pain à Marie.
Jean AUX.3SG make.PTCP cut DEF bread to Marie
'Jean made Marie cut the bread.'

b. [do' (Jean, Ø)] CAUSE [[do' (Marie, Ø)] CAUSE [BECOME cut' (pain)]]

c. Jean a fait couper le pain par Marie. Jean AUX.3SG make.PTCP cut DEF bread by Marie 'Jean had Marie cut the bread.'

d. $\left[\mathbf{d o}^{\prime}(\right.$ Jean, $\left.\varnothing)\right]$ IND $\left[\left[\mathbf{d o}^{\prime}\right.\right.$ (Marie, Ø)] CAUSE [BECOME

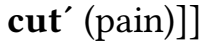

e. $\quad\left[\mathbf{d o}^{\prime}\left(\right.\right.$ Jean, Ø)] CAUSE $\left[\left[\mathbf{d o}^{\prime}\right.\right.$ (Marie, Ø)] CAUSE [BECOME cut' (pain)]]

f. Jean a coupé le pain avec un Jean AUX.3SG cut.PTCP DEF bread with INDEF couteau.

knife

'Jean cut the bread with a knife.' 
g. $\quad\left[\mathbf{d o}^{\prime}(\mathrm{Jean}, \varnothing)\right] \mathrm{CAUSE}\left[\left[\mathbf{d o}^{\prime}(\right.\right.$ couteau, $\left.\varnothing)\right] \mathrm{CAUSE}$ [BECOME cut' (pain)]]

h. *Jean a fait couper le pain à

Jean AUX.3SG make.PTCP cut DEF bread to

le couteau.

DEF knife

'* Jean made the knife cut the bread.'

i. $\quad{ }^{*}\left[\mathbf{d o}^{\prime}(\right.$ Jean, $\left.\varnothing)\right]$ IND $\left[\left[\right.\right.$ do' $^{\prime}$ (couteau, Ø)] CAUSE [BECOME

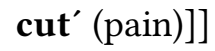

The examples in (11f-11i) illustrate that the instrument can only be under the scope of direct causation. Using the causee construction is not admissible and thus the type of causation cannot be indirect, as illustrated in (11i). Even though there is a tendency for causees to be under the scope of indirect causation, they can also be under the scope of direct causation. This is illustrated by the examples in (11a-11e). Even though there is no physical manipulation in (11a) as with instruments, I assume that the directness of impingement in that example is the product of metaphoric extension of prototypical physical manipulation to socio-psychological pressure (cf. Talmy 2000: 409). In terms of the system I proposed in chapter 5, this kind of causation would count as semi-physical. ${ }^{4}$ That does not mean, however, that the precise type of causation with causees is always clear. Consider for example the conversation in (12), where the second speaker asks for clarification by stressing the assumed direct nature of causation.

(12) Speaker 1: My boss made me tidy up my office.

Speaker 2: He MADE you?

Speaker 1: Well, he asked me to.

Contrary to causees, typical instruments can never be under the scope of indirect causation or any kind of causation weaker than that as evidenced by the English examples in (13).

4 Causees can also be under permissive and enabling causation, as was shown in chapter 5. This is irrelevant for the present discussion, however. The LSs in (11d) and (11i) have IND for illustration purposes only. I assume the underspecified CAUSE, however. 
(13) a. *Fohn had the sword destroy the sign.

b. *John let the sword destroy the sign.

c. "Abdul had the knife cut the cake.

d. *Abdul let the knife cut the cake.

In chapter 4, it was established that pseudo-agents have special properties: They can be conceptualized as instruments or as instigators. Similar to causees operating under direct causation, some pseudo-agents can also operate under indirect causation ((14)).

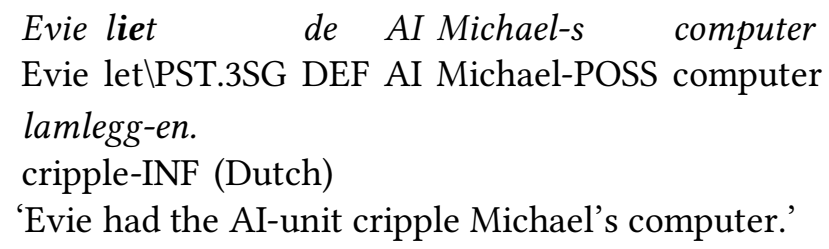

As pseudo-agents can be instigators in their own right, I propose to treat $A I$ in the Dutch example above as a causee and not as an instrument. The potential for causeehood on the part of pseudo-agents is also indicated in the graph in figure 37 by means of the overlapping areas. In other words, pseudo-agents can be conceptualized as instigators, instruments and causees.

In chapter 5, it was argued that causees can act either volitionally or non-volitionally and these concepts were decomposed using FD. If the auxiliary or other causal morphology does not entail any information regarding intention, Holisky's principle applies. For example, in Quechua (15), causees can be marked with accusative, in which case they are read as acting non-volitionally (Van Valin \& LaPolla 1997: 588, Van Valin \& Wilkins 1996: 311-312, examples from Bills et al. 1969). If the causee is marked with the instrumental, it can be interpreted as either volitionally or non-volitionally acting, whereas accusative marking only allows for the non-volitional reading. In the former case, Holisky's principle applies.

$$
\begin{aligned}
& \text { a. Nuqa Fan-ta rumi-ta apa-ci-ni. } \\
& \text { 1SG Juan-ACC rock-ACC carry-CAUSE-1SG } \\
& \text { 'I made Juan carry the rock.' }
\end{aligned}
$$


b. Nuqa Fan-wan rumi-ta apa-ci-ni. 1SG Juan-INS rock-ACC carry-CAUSE-1SG 'I had Juan carry the rock.'

A similar situation exists in French (Van Valin \& Wilkins 1996: 311-312, examples from Hyman and Zimmer 1976). In (16a), any volitional reading on the part of the causee is blocked by the use of $\dot{a}$. The use of par allows for both a volitional and a non-volitional reading. I will return to this issue in chapter 8.

$$
\begin{aligned}
& \text { a. F'ai fait nettoyer les toilettes au } \\
& \text { 1SG=AUX do.PTCP clean.INF DEF toilets to.DEF } \\
& \text { général. } \\
& \text { general } \\
& \text { 'I made the general clean the toilets.' } \\
& \text { b. F'ai fait nettoyer les toilettes par } \\
& \text { 1SG=AUX do.PTCP clean.INF DEF toilets by } \\
& \text { le général. } \\
& \text { DEF general } \\
& \text { 'I had the general clean the toilets.' }
\end{aligned}
$$

Dutch has an auxiliary that precludes any voluntary reading of the causee (doen) and it has a second auxiliary (laten) that does not entail any information concerning volition on the part of the causee. Consider (17):

a. Lara liet Tim het afval buiten zett-en,

Lara let\PST Tim DEF trash outside put-INF

$$
\text { maar deed dat tegen zijn zin. }
$$

but do\PST.3SG DEM against POSS preference

'Lara made Tim take out the trash, but he only did so against his will.'

b. Lara liet Tim het afval buiten zett-en

Lara let\PST.3SG Tim DEF trash outside put-INF

en hij deed dat met plezier.

and 3SG do\PST.3SG DEM with pleasure

'Lara had/let Tim take out the trash and he did so willingly.' 


\section{c. *Lara deed Tim het afval buiten zett-en}

Lara do\PST.3SG Tim DEF trash outside put-INF

en hij deed dat met plezier.

and 3SG do\PST.3SG DEM with pleasure

'*Lara made Tim take out the trash and he did so willingly.'

If one were to use laten without any further information, the causee would be interpreted as acting intentionally. By contrast, the causee in (17c) is always interpreted as acting non-intentionally. In the Dutch examples in (5.40), use of door fixes the reading of causation to $\mathrm{IND}^{5}$, whereas the use of aan sets it to permissive/enabling. If no preposition is used, the type of causation is underspecified and the reading of the causee is determined by Holisky's principle. ${ }^{6}$ In French too, the use of a certain preposition is indicative of the type of causation: $\grave{a}$ fixes the type of causation to direct causation, leaving no room for interpretation. The use of $\dot{a}$ constitutes 'information to the contrary' in terms of Holisky's principle. If par is used, causation is set to indirect and Holisky's principle determines the precise reading of causee: Adding information signaling willingness, yields a contradiction for (18a) but not for (18b).

$$
\begin{aligned}
& \text { a. 'F'ai fait } \quad \text { nettoyer les toilettes } \\
& \text { 1SG=AUX make.PTCP clean.INF DEF toilet.PL } \\
& \text { au général et il l'a } \\
& \text { to.DEF general and 3SG OBJ=AUX.3SG want.PTCP } \\
& \text { 'I made the general clean the toilets and he wanted to.' }
\end{aligned}
$$

\footnotetext{
5 Recall that the use of door makes the volitional reading less likely but does not rule it out (see chapter 5 ).

$6 \quad$ Verhagen and Kemmer (1997: 79) argue that if no preposition is used, the default reading is that of a non-volitional causee. My own native speaker intuitions are at odds with this and they confirm Holisky's principle. Verhagen and Kemmer argue that including and she did a fine job in sentences with laten (without a preposition) is not appropriate. There are two problems with this: 1) Such an addition is no real test for volition and 2) in my variety of Dutch it would be appropriate to add the sequence.
} 
b. J'ai fait nettoyer les toilettes par 1SG=AUX make.PTCP clean.INF DEF toilet.PL by le général et il l'a voulu. DEF general and 3SG OBJ=AUX.3SG want.PTCP 'I had the general clean the toilets and he wanted to.'

In German, there is only one causative auxiliary, lassen ((19)). Here, too, Holisky's principle determines whether the causee is understood as intentional or non-intentional. Contrary to French and Quechua, there is no morphological means to explicitly express a non-volitional reading. The preposition von is used for the purposes of disambiguation with animates, but has no further implication for the volitionality of the causee. In (19d), the argument marked by von indicates that it is the causee and not the person kissed. Without von, the sentence is ambiguous with respect to who is kissed.
a. Lara lie $\beta \quad$ Tim den Müll wegbring-en.
Lara let\PST.3SG Tim DEF trash take away-INF
'Lara had/made/let Tim take out the trash.'
b. Lara ließ $3 \quad$ Tim den Müll wegbring-en
Lara let|PST.3SG Tim DEF trash take away-INF
und er tat es sogar freiwillig.
and 3SG do\PST.3SG 3SG.O even voluntarily
'Lara had Tim take out the trash and he even did so voluntarily.'
c. Lara ließ Tim den Müll wegbring-en, Lara let\PST.3SG Tim DEF trash take away-INF aber er tat es nur unfreiwillig. but 3SG do\PST.3SG 3SG.O only involuntarily 'Lara had Tim take out the trash, but he only did so involuntarily.'
d. Lara ließ Tim von Maria küss-en.
Lara let\PST.3SG Tim by Maria kiss-INF.
'Lara had Maria kiss Tim.' 
I will return to causee-marking in chapter 8 . To summarize the properties of all classes of referents that can be intermediate effectors, I have provided table 25 . The values in the table are valid for prototypical instruments and causees. For the sake of clarity, I have also included pseudoagents. Bear in mind, however, that these are referents that can be conceptualized as either instruments or causees. Type of causation refers to the type they are typically found under the scope of. Actionality refers to the position on the actionality scale. If more than one type of causation is listed, the first one mentioned is the most usual one.

\begin{tabular}{|l|l|l|}
\hline & Type of causation & Actionality \\
\hline Instrument & Direct & Mid-range \\
\hline Causee & Indirect/Direct & Very high \\
\hline Pseudo-agent & Direct/Indirect & High \\
\hline
\end{tabular}

Table 25: Summary of intermediate effector classes.

\subsubsection{Causees taking instruments}

Since I posit that causees and instruments typically occupy the same position in the LS (at least in French), some sentences with both could potentially pose a problem. Consider:

$$
\begin{aligned}
& \text { Jean a fait couper le pain } \\
& \text { Jean AUX.3SG make.PTCP cut.INF DEF bread } \\
& \dot{a} \text { Marie avec un couteau. } \\
& \text { to Marie with INDEF knife } \\
& \text { 'Jean made Mary cut the bread with a knife.' }
\end{aligned}
$$

Assuming that the instrument and the causee occupy the same argument position in the LS, how do we account for examples like (20)? The most natural reading of (20) is that Jean had Marie cut the bread and Marie used a knife to arrive at this result. Before any LS can be proposed, it has to be ascertained whether both Marie and couteau are causally embedded. This can be done by testing every individual segment of the causal chain with the causal paraphrase. Applying the test reveals that the two arguments 
are, in fact, causally embedded $((21 \mathrm{a}-21 \mathrm{~b}))$ and that couteau is not under the direct scope of fean $((21 \mathrm{c}))$.

$$
\begin{aligned}
& \text { a. Jean a agit sur Marie, ce qui } \\
& \text { Jean AUX.3SG act.PTCP on Marie REL } \\
& \text { a causé qu'elle coupe le pain } \\
& \text { AUX.3SG cause.PTCP that=3SG.F cut.3SG DEF bread } \\
& \text { avec un couteau. } \\
& \text { with INDEF knife } \\
& \text { 'Jean acted on Mary, causing her to cut the bread with a } \\
& \text { knife.' } \\
& \text { Marie AUX.3SG act.PTCP on DEF knife REL } \\
& \text { a causé qu'il coupe le } \\
& \text { AUX.3SG cause.PTCP that=3SG.M cut.3SG DEF } \\
& \text { pain. }
\end{aligned}
$$

a causé qu'il coupe le pain.

To adequately capture what the paraphrases in (21) revealed, adding another causal sequence to the LS is the most straightforward solution. The LS of (21a) is given in (22).

(22) $\left[\right.$ do' $\left.^{\prime}(J e a n, \varnothing)\right]$ CAUSE $\left[\left[\right.\right.$ do' $^{\prime}$ (Marie, Ø)] CAUSE [[do' (couteau, Ø)] CAUSE [BECOME cut' (pain)]]]

There is a marginal reading of (20), where fean uses the knife to make Marie do something and that something is to cut the bread. This reading of (21a) also passes the causal paraphrase. Fean acts on the knife, which in turn acts on Marie which causes her perform an activity. Bear in mind that such an interpretation is very marked and not a single informant indicated it as the default interpretation. 
So far, causees so far have been intermediate effectors, i.e. as effectors followed by at least one causal operator. However, contrary to instruments, causees do not have to be intermediate. It is more apt to define them as non-initial effectors. Consider the following examples from French and Dutch:

$$
\begin{aligned}
& \text { a. Jean a fait manger Marie avec } \\
& \text { Jean AUX.3SG make.PTCP eat.INF Marie with } \\
& \text { une fourchette. } \\
& \text { INDEF fork } \\
& \text { 'Jean made Marie eat with a fork.' (French) } \\
& \text { b. Jean heef-t Marie met een vork doe-n } \\
& \text { Jean AUX-3SG Marie with INDEF fork do-INF } \\
& \text { et-en. } \\
& \text { eat-INF } \\
& \text { 'Jean made Marie eat with a fork.' (Dutch) } \\
& \text { Marie a mangé avec une fourchette. } \\
& \text { Marie AUX.3SG eat.PTCP with INDEF fork } \\
& \text { 'Marie ate with a fork.' (French) } \\
& \text { Marie at met een vork. } \\
& \text { Marie eat|PST.3SG with INDEF fork } \\
& \text { 'Marie ate with a fork.' (Dutch) }
\end{aligned}
$$

The sentence in (23a) has two relevant interpretations: 1) Jean makes $M a$ rie do something, and that something is eating with a fork and 2) Jean makes Marie eat, poking her with a fork to achieve this. The LS of the first interpretation is given in (24a) and the LS of the second one is given in (24b).
a. $\quad\left[\right.$ do' $^{\prime}($ Jean, $\left.\varnothing)\right]$ CAUSE $\left[\right.$ do' $^{\prime}$ (Marie, [eat' $($ Marie, $\varnothing) \wedge$ use' $^{\prime}$ (Marie, fourchette)])]
b. $\quad\left[\mathbf{d o}^{\prime}(\mathrm{Jean}, \varnothing)\right]$ CAUSE $\left[\left[\mathbf{d o}^{\prime}\right.\right.$ (fourchette, Ø)] CAUSE [do' (Marie, [eat' (Marie, Ø)])]]
c. do' (Marie, [eat' (Marie, $\varnothing) \wedge$ use' $^{\prime}($ Marie, fourchette)]) 
Fork in (23a) under interpretation 1) is an implement as it would fail the causative paraphrase. Furthermore, it would unambiguously be an implement in the more basic example in (23c). Its LS is given in (24c).

There is an important principle behind the phenomenon where causees take instruments: The instrument has to be lower in the LS (i.e. more to the right) than the causee governing it. In other words, there is a relative ordering: Causees normally precede instruments. Consider the examples in (25) where this principle is violated.

(25) a. *Fohn made the cannon make Bill destroy the barn.

b. * *John made/had/let the cannon make Bill destroy the barn.

c. "Fohn deed het kanon Bill de schuur

John dolPST.3SG DEF cannon Bill DEF barn vernietig-en.

destroy-INF

'*John made the cannon make Bill destroy the barn.' (Dutch)

d. "Fohn deed het kanon de schuur met Bill

John do\PST.3SG DEF cannon DEF barn with Bill vernietig-en.

destroy-INF

'*John made the cannon destroy the barn with Bill.'

In chapter 4, the Relative Power Principle was introduced to govern the relative ordering of pseudo-agents and instruments. The examples in (25) illustrate that this principle, or rather an extension thereof, also governs the occurrence of instruments and causees in the same sentence. An updated version of the principle is given in (26).

(26) Relative Power Principle (final): Save for other considerations, the referent filling an effector slot $(\alpha)$ in the logical structure must be ranked higher on the actionality scale than the referents of effector arguments that are embedded deeper in the logical structure than $\alpha$.

This new formulation of the principle covers all cases that were covered by the provisional principle in chapter 4 . In addition, it covers the distribution of causees, instruments and agents. Typical causees are just 
as human as typical agents, yet are tacitly assumed to be less powerful. In causee constructions the instigator is considered to be in a position of (more) power:

a. John made Bill cut down the tree.

b. The general had the sergeant make the call.

c. ?The sergeant had the general make the call.

In (27a), fohn is interpreted as having some power over Bill. If both were reversed, Bill would be considered as having power over fohn. This variable actionality is of the induced kind and depends (in this case) on contextual knowledge. I therefore regard human causees as slightly less actional than human agents. In (27b) on the other hand, this power differential is lexicalized. Switching both arguments yields a less acceptable sentence (27c).

The revised principle in (26) contains the wording save for other considerations. This refers to examples such as (23a) under the second interpretation. Here, the instrument ranks higher than the causee in the LS. However, as I pointed out before, such interpretations are very marked and never constitute the default interpretation. It seems that the principle in (26) is not absolute in the sense that a violation results in ungrammaticality. Deviating from (26) does, however, result in a very marked structure.

\subsubsection{Expanding the effector role}

In Van Valin \& Wilkins (1996), the anatomy of the effector role was investigated. Three main readings of effector were distinguished: 1) agent, 2) instrument and 3) force. The authors defined the readings of the effector role according to mainly two properties, namely the position of the effector (intermediate vs. instigating) and the nature of the referent (human vs. inanimate). In the previous chapters, I have investigated forces, instruments and causees. For example, it was established that forces typically occupy a very specific section of semantic space, centered around the concept of para-autonomous. I believe it would be advantageous to refine the existing 1996 classification and to include two new subtypes: the causee and the executor. The executor is simply a label for non-agentive human instigators, i.e., human instigators whose default agency is canceled. Van 
Valin and Wilkins (1996) do recognize non-agentive human effectors, but they do not include them in the list of effector subtypes. If a subclassification of effector is not useful, it suffices to use the term effector or plain effector. For instance, if there is only single argument, such as with intransitives (e.g. The ball is rolling), it does not seem necessary to provide a classification beyond plain effector. I have not included free and blocked instruments or pseudo-agents. Pseudo-agents are not so much an effector subtype rather than a specific class of referents that can be conceptualized as both instruments and instigators. Free and blocked instruments do not constitute a subtype either, as they are both simply instruments. Recall that this distinction is purely terminological in nature: A free instrument is an instrument that can undergo ISA with a given predicate and in a certain language. Mes in examples (3.50e-3.50f) is a blocked instrument in Dutch but would be a free instrument in the English equivalent. Free and blocked are nothing more than labels to describe the behavior of referents; they do not imply any deeper theoretical distinction.

\begin{tabular}{|l|l|l|l|l|l|}
\hline \multirow{2}{*}{ Feature } & \multicolumn{5}{|c|}{ Effector subtypes } \\
\cline { 2 - 6 } & $\begin{array}{l}\text { Agen } \\
\text { t }\end{array}$ & Executor & Force & Causee & Instrument \\
\hline Instigator & Yes & Yes & Yes & No & No \\
\hline $\begin{array}{l}\text { Causation } \\
\text { type }\end{array}$ & N/A & N/A & N/A & (In)direct & Direct \\
\hline $\begin{array}{l}\text { Metonymic } \\
\text { clipping }\end{array}$ & N/A & N/A & N/A & No & Yes/No \\
\hline $\begin{array}{l}\text { Actionality } \\
\text { HP rele- } \\
\text { vant }\end{array}$ & Yes & High & $\begin{array}{l}\text { Para-au- } \\
\text { tonomous }\end{array}$ & High & Mid \\
\hline Volitional & Yes & No & No & Yes & No \\
\hline
\end{tabular}

Table 26: Summary of proposed effector subtypes. 
Causees are listed as being under (in) direct causation: They can be under the scope of indirect causation, but can also be licensed under direct causation. Instruments are given the value Yes/No with respect to metonymic clipping. This refers to the fact that some instruments allow for ISA but others do not. The actionality row refers to the portion of semantic space that the subtype's referents are typically located in. HP relevant refers to whether Holisky's principle is relevant. It is only relevant for agents, executors and causees because the principle primarily affects human referents. Lexical agents or agenthood imposed by a construction are not covered. This field only concerns HP-derived agents. Volitional refers to whether the referent is inherently acting volitionally or not.

\subsection{Comitatives}

In RRG, comitatives are essentially conjoined arguments where one is coded with a with-PP (but need not be). As I pointed out in the introduction of this chapter, there is a superficial similarity in many languages between comitatives and instruments. Even though more languages make a morphosyntactic distinction between the two, most languages spoken natively in Europe do not make such a distinction (Stolz et al. 2013: WALS entry), Finnish being a notable exception. Comitatives are said to express the notion of accompaniment of two entities (Ibid.). Yet, there also appears to be a criterion of co-authorhood for the most prototypical comitatives, as shown in (28a).

(28) a. John ran to the store with Mary.

b. John ran to the store with his goldfish.

c. John ran to the store with his hammer.

In (28b), goldfish is not a co-author, as the animal is confined to water and cannot run parallel to fohn. Similarly, in (28c), hammer, being quite low on the actionality scale, cannot be co-autor of the action described by the predicate. In this section, I will explore the RRG-approach to comitatives and attempt to provide an account of examples such as (28b) and (28c). 


\subsubsection{True comitatives}

Normal (or 'true') comitatives are treated as a linking option in RRG (Van Valin \& LaPolla 1997: 379, Van Valin 2013: 73ff., cf. Jolly 1993). Essentially, these prototypical comitatives are tied in to the actor macrorole: One of the arguments will function as the actor. As far as logical structures are concerned, comitatives are treated as conjoined arguments of the form (X $\wedge \mathrm{Y}$ ) where one of the arguments is alternatively coded in a with-PP. The necessary characteristic for comitatives is so-called co-authorhood. Coauthorhood is a preliminary term to denote that both arguments in question are considered to be authors of the state or activity. This is evidenced by two alternations that can be used as tests: 1) The ability to occur without PP-coding and 2) the interchangeability of the arguments. Regarding 1), Koenig et al. (2008: 181) suggest paraphrasing the sentence under investigation as $X$ and $Y V$-ed. This is illustrated in (29b) and (29d), and alternation 2) is illustrated in (29b-29d). I propose to treat arguments that pass both tests as co-authors. Instruments, contrary to comitatives, does not pass Koenig's proposed paraphrase ((29f-29i)). The logical structure underlying (29a-29d) is given in (29e). I choose to use co-authorhood while rejecting the notion of co-agency because comitatives can be non-agentive, as shown by the acceptability of $(29 \mathrm{j}-29 \mathrm{k})$.

(29) a. John walked with Sonia.

b. John and Sonia walked.

c. Sonia walked with fohn.

d. Sonia and John walked.

e. $\quad$ do' $^{\prime}(\mathrm{John} \wedge$ Sonia, [walk' $(\mathrm{John} \wedge$ Sonia)]

f. John broke the cup with the hammer.

g. "John and the hammer broke the cup.

h. Sonia cut off the leaf with a knife.

i. $\quad$ *Sonia and the knife cut off the leaf.

j. Sonia and John drank all the wine together, but they did not intend to.

k. Sonia drank the wine with fohn, but they did not intend to. 
Comitatives are primarily a morphosyntactic phenomenon, where alternative coding is used for pragmatic purposes. Both arguments can be selected as actor, or one argument can receive with-coding. In case of the latter, the alternatively coded argument is not selected as actor but becomes an oblique core argument and is marked by with following the standard linking rules for non-macrorole arguments. It is for this reason that I equally reject the alternative terminology of co-actorhood (instead of co-authorhood), because this would be confusing from a linking perspective. In the examples below (adapted from Van Valin 2013: 91), all three realizations again have the same underlying LS (given in (30d)), irrespective of voice-oppositions.

(30) a. The gangster robbed the bank (together) with the corrupt policeman.

b. The bank was robbed by the gangster (together) with the corrupt policeman.

c. The bank was robbed by the corrupt policeman (together) with the gangster.

d. [do' (gangster $\wedge$ corrupt policeman)] CAUSE [BECOME NOT have' (bank, Ø)]

Van Valin (2013: 103) points out that the qualia-properties of the referents are crucial for the comitative interpretation of with. In other words, the object of with in (30a-30b) is interpreted as being in a comitative relationship with gangster because its qualia-properties describe it as a human, capable of doing a certain activity. These properties are stored on the telic qualia layer (or: quale). Van Valin (2013: 100) represents these properties for a referent such as Kim as in (31).
a. $\quad \operatorname{Kim}(a)$
b. Telic: do' $(a,[\ldots])$

This information is the reason why the sentence in $(30 \mathrm{a}-30 \mathrm{~b})$ is interpreted as comitative rather than, say, instrumental. The arguments pass both tests for co-authorhood ((32)), because the qualia-properties of gangster and corrupt policeman are essentially the same (i.e. human, capable of performing certain activities). 
(32) a. The gangster and the corrupt policeman robbed the bank.

b. The corrupt policeman and the gangster robbed the bank.

c. The corrupt policeman robbed the bank with the gangster.

\subsubsection{Undergoer \& NMR comitatives}

Jolly (1993: 300-301) explores a phenomenon that is said to use the same mechanics as the true comitatives and can be considered the undergoerversion of the comitative. Consider the example in (33a) and the LS Jolly proposes for it in (33b).

(33) a. John served the entree with the soup to his guests. (adapted from Jolly 1993: 300)

b. [do' (John, Ø)] CAUSE [BECOME have' (guests, entree $\wedge$ soup)]

Jolly assumes that the RP entree $\wedge$ soup functions along the same lines as far as argument marking is concerned: Entree is selected as undergoer, leaving soup as an NMR marked by with. As is the case with the more typical comitatives, the order of the nouns can be switched and the withcoding is not obligatory but optional:

(34) a. John served the entree with the soup to his guests.

b. John served the soup with the entree to his guests.

c. John served his guests the entree and the soup.

d. John served his guests the soup and the entree.

As serve behaves like a dative shift verb, it is possible to assign the undergoer macrorole to guests, leaving entree $\wedge$ soup as the NMR. This is given in $(34 \mathrm{c}-34 \mathrm{~d})$. Yet, even with this alternative undergoer assignment pattern, it is possible to mark one of the arguments by with (35a). Here, too, the order can be switched ((35c)). The LS for (35a) is given in (35b).

(35) a. Fohn served his guests the entree with the soup.

b. [do' (John, Ø)] CAUSE [BECOME have' (guests, entree $\wedge$ soup)] A U $\quad \mathrm{NMR}_{1}$ $\mathrm{NMR}_{2}$

c. John served his guests the soup with the entree. 
In case of two NMRs, it appears that the one that is least pragmatically salient is marked by with, paralleling the pragmatic assumptions surrounding variable undergoer selection. In case of variable undergoer selection, the lowest-ranking argument is selected as NMR and is marked by with. Compare: John presented the pad to Eliza vs. John presented Eliza with the pad. The example given in section 6.2 is one of dative shift. Dative shift verbs, contrary to transfer verbs, are exempt from marking the non-default NMR by with (Van Valin 2005: 114). However, the logic of pragmatic modulation in both these types of variable undergoer selection is the same. I assume that the reason for alternatively coding one of the two argument in (33a) and (35b) is driven by the same motivation: The most topical of the two arguments is left unmarked. The least topical one is marked by with. In the case of (33a), one is selected as undergoer and the other becomes an NMR. In (35b), one NMR is split into two. NMR-splitting seems to follow the same logic of pragmatic modulation by extension. It appears that the term comitative is much broader than co-authorhood and also includes (at least) a form of co-undergoerhood. As comitatives are essentially a linking-option, I will return to them in chapter 8 .

\subsubsection{Comitatives with inanimate components}

Most comitative examples contain human referents and co-authorhood is a useful criterion. As pointed out by Schlesinger (1989: 201), sentences like fohn and the key opened the door are ungrammatical. In terms of the approach in the previous sections, the two arguments cannot be conjoined because their referents' qualia-properties do not match. Using the two paraphrases proposed above, the more basic example in (36a) is identified as an instrument construction and not as a comitative.
a. John opened the door with the key.
b. "Fohn and the key opened the door.
c. "The key and fohn opened the door.
d. "The key opened the door with fohn.

However, it would be dubious to explain the acceptability of the sentences in (37) (adapted from Schlesinger 1989: 201f.) with matching qualia-structures. 
a. Floods and guerilla forces ravaged the area.

b. The battleship and the Admiral bombarded the coast.

It is clear that the referents in these sentences are not directly similar in nature. A battleship is an inanimate that does not have a will of its own and is in all likelihood commanded by the other referent, Admiral. Yet, despite this difference, such sentences are still grammatical, contrary to the ones in (38).

(38) a. *The general and the sword cut open the suit of armor.

b. $\quad$ "The farmer and the plow plowed the field.

I propose that the conjunction of arguments is constrained by the position of their referents on the actionality scale: Only if each of the referents could function as the sole x-argument of the relevant LS can such conjunction successfully occur. The sentence * Fohn and the key opened the door is not admissible because it fails this requirement: fohn and key cannot occupy the same position (or a similar one) in the logical structure. The ability to function in the same slot depends on the referents being (rather) close in terms of the actionality scale. Consider:

(39) a. Fohn opened the door.

b. [do' (John, Ø)] CAUSE [BECOME open' (door)]

c. John opened the door with a key.

d. [do' (John, Ø)] CAUSE [[do' (key, Ø)] CAUSE [BECOME open' (door)]]

e. The key opened the door.

f. $\quad\left[\right.$ do' $\left.^{\prime}(\varnothing, \varnothing)\right]$ CAUSE $\left[\left[\mathbf{d o}^{\prime}(\mathrm{key}, \varnothing)\right]\right.$ CAUSE [BECOME open' (door)]]

g. $\quad$ * $[$ do' (key, Ø)] CAUSE [[do' (levers, Ø)] CAUSE [BECOME open' (door)]]

h. $\quad$ "The key opened the door with the levers.

In (39a-39d), fohn and key respectively occupy the instigator and instrument position in the logical structures. As I have shown, an instrument undergoing ISA is still in its intermediary position. It cannot be an instigator, as evidenced by $(39 \mathrm{e}-39 \mathrm{~h})$, where an attempt to move key to 
instigator position with an additional instrument results in ungrammaticality. In (40) below, the LS is the same, because both referents could be instigators in their own right. The LS for (40a) is given in (40g).

(40) a. John and the computer virus disabled Mary's computer.

b. John disabled Mary's computer.

c. [do' (John, Ø)] CAUSE [BECOME disabled' (Mary’s computer)]

d. The computer virus disabled Mary's computer.

e. [do' (computer virus, Ø)] CAUSE [BECOME disabled' (Mary's computer)]

f. The computer virus disabled Mary's computer with spam.

g. $\quad\left[\mathbf{d o}^{\prime}(\mathrm{John} \wedge\right.$ computer virus, $\left.\varnothing)\right]$ CAUSE [BECOME disabled' (Mary's computer)]

One could argue that co-authorhood should be 'broadened' to include inanimates that are high enough on the actionality scale and that comitatives with inanimate components should be considered as ordinary, typical comitatives. As soon as there is co-authorhood, alternative coding is possible. This would be false, as the sentences in (40) do not allow for alternative coding like normal comitatives, despite being conjoined. Fohn and computer virus are both co-authors, as evidenced by (40), yet alternative coding is not possible:

*Fohn disabled Mary's computer with the computer virus.

The sentence in (41) is not an admissible alternatively coded version of the one in (40a). It can only have the classic instrument reading and would always link back to the logical structure in (42).

(42) [do' (John, Ø)] CAUSE [[do' (computer virus, Ø)] CAUSE [BECOME disabled' (Mary's computer)]]

It thus seems that co-authorhood is not a sufficient criterion. Even if coauthorhood is present, alternative coding is only allowed if the actionality level of the conjoined arguments is as good as identical. Prototypically, this involves two instances of the same species, class or type. The second 
sentence in each of the pairs below receives the standard comitative interpretation, even if the referents are inanimates.
a. The tornado and the hurricane destroyed the barn.
b. The tornado destroyed the barn (together) with the hurricane.
c. The first and the second assembly robot assembled the car.
d. The first assembly robot assembled the car (together) with the second assembly robot.

There are of course instances where the structural criterion I proposed earlier is seemingly met, yet the sentence is still not admissible ((44a)). The logical structure of (44b) is given in (44c). Schlesinger believes that (44b) and (44d) describe the same state of affairs. He therefore believes that the difference in membership is what makes (44a) inadmissible. Even though I attribute some explanatory power to degrees of membership (in my proper terminology actionality status), I believe there is a structural explanation here. It seems strange to posit stick as an effector and, furthermore, it cannot take an instrument itself. Therefore, it cannot be an initial effector. Apart from a potential ISA-reading, contexts can be conjured up to account for (44d) where there is no instigator and the stick falls because of natural causes. Even though gravity (or other natural causes) might be an instigator in the purely physical realm, it is hardly ever constructed as an instigator linguistically. Yet, a non-ISA interpretation is quite plausible from a language user's point of view. A non-ISA interpretation would mean that the stick is a force, which it cannot be according to the actionality scale. Rather than assuming an exception captured by a construction or making an exception to the actionality scale, there is a much simpler solution. I propose to treat Carol in (44b) as a normal effector, subject to the actionality hierarchy. Example (44d), however, is to be analyzed as a predicate of location, making stick a mover. The requirement for predicates of motion are generally lower and the referent stick - by virtue of being mobile - meets the requirements for that LS's x-argument. This might seem ad hoc, but the meanings of (44b) and (44d) are actually quite distinct. The former captures a state of affairs where an individual inflicts pain on another entity. The latter denotes an 
object impacting another. Aktionsart-testing is difficult as hit is very polysemous. The Dutch and German equivalents are clearer because they use different verbs. Both raken and treffen test as achievements. Evidence for the analysis of (44d) as a motion predicate comes from Dutch and German (for example), where two different verbs are employed ((44f-44k)).
a. $\quad{ }^{*}$ Carol and the stick hit the horse. (adapted from
Schlesinger 1989: 201)
b. Carol hit the horse.
c. do' (Carol, [hit' (Carol, horse)])
d. The stick hit the horse.
e. INGR be-at' (stick, horse)
f. Carol sloeg het paard.
Carol hit PST.3SG DEF horse (Dutch)
g. De stok raak-te het paard.
DEF stick hit-PST.3SG DEF horse
h. ${ }^{*}$ De stok sloeg het paard.
DEF stick hit \PST.3SG DEF horse
i. Carol schlug das Pferd.
Carol hit $\backslash$ PST.3SG DEF horse (German)
j. Der Stock traf das Pferd.
DEF stick hitlPST.3SG DEF horse
k. *Der Stock schlug das Pferd.
DEF stick hit $\backslash$ PST.3SG DEF horse

Thus, despite the fact that both states of affairs are coded with the same verb, they relate to different logical structures, which are expressed by different verbs in Dutch and German. Stick cannot occupy the position that Carol occupies in (44c) and therefore conjunction is impossible. Therefore, the structural criterion I proposed holds: Only one can fill the argument position in the LS but the other cannot.

In this section I illustrated that inanimates can be conjoined with animates. Essentially, such cases can be treated like normal comitatives, i.e. conjoined arguments. There is a crucial condition for this to be possible: Each of the conjoinees must be able to independently function in the same 
position in the same logical structure. ${ }^{7}$ I propose to use this criterion as a refinement of co-authorhood as the prerequisite for conjoined arguments for a given argument position. A referent's ability to function as such depends on its position on the actionality scale to a large degree (i.e. it must be in the correct portion of semantic space).

Alternative coding, however, is an option that is reserved to two coauthors that have the same actional status. Schlesinger (1989: 202) refers to this as the necessity for the degree of membership to be similar. Normal comitatives feature human referents which occupy the same position on the actionality scale. Because of this, they are not only co-authors, but the similarity in actionality also allows for the alternative linking with a with$\mathrm{PP}$. As soon as one of the referents is significantly lower than the other, the alternative linking option disappears because of preferred linking back to an instrument-LS. If there is no co-authorhood, the conjunction of arguments becomes impossible. As has become clear in this section and the previous one, comitatives are a much wider phenomenon than human coauthors, even though the latter constitute the prototypical instance of the class.

It is easier to generalize with my proposal than it is to generalize with statements of the type "only forces and forces or forces and agents may be conjoined". Given the fact that there is a class of referents that can be both instruments and instigators (pseudo-agents, see chapter 4), the discrete nature of such statements would pose challenges.

The three types of comitatives explored so far all share a crucial characteristic, which I call positional equivalence. Whether with the 'actor'version, the 'undergoer'-version or the 'NMR'-version, the arguments in question have to be positionally equivalent. That is, they have to be able to occupy the relevant position in the LS individually and when conjoined. If there is positional equivalence, the comitative operation can take place: One of the two arguments is alternatively coded. With 'actor'-comitatives,

7 Needless to say, initial $x$-argument positions of logical structures will require a higher actional status from their prospective referents than argument positions lower in the logical structure. In a way, Schlesinger (1989: 201) has a point when he states that the 'instrument' that is conjoined must have a similar degree of membership to the 'agent'. 
there is an added complexity in that the actionality status of the arguments' referents must be similar enough. The driver behind alternative linking (if it is possible) is pragmatic in nature. Actors are default topics. By selecting only one of the arguments as the actor, it alone becomes the topic. Likewise, undergoers are more topical than NMRs. Therefore, selecting only one argument as undergoer is a strategy to modulate the pragmatics. The same logic can be extended to the NMR-version of the comitative.

\subsubsection{Inanimate comitatives}

There is also a second phenomenon where an inanimate component occurs in a seemingly comitative construction. I propose to call this subtype inanimate comitatives. ${ }^{8}$ Consider:
a. John ran to the store with Mary.
b. John ran to the store with his hammer.
c. John and Mary ran to the store.
d. "Fohn and the hammer ran the store.
e. * Fohn acted on the hammer, causing it to run to the store.
f. */?fohn ran to the store and simultaneously used the hammer.
g. *The hammer facilitated the running to the store.

In (45b), the runner moves to the store and his hammer makes the same journey. Contrary to the type discussed above, these referents do not meet the structural criterion: The referent hammer cannot function in the same logical structure as fohn. This is exemplified in (45c) and (45d). In other words, it cannot be a comitative. The hammer is not embedded in a causal chain $((45 e))$ or under the scope of helping causation $((45 f-45 g))$. Therefore, it cannot be an instrument, a causee or an implement. Then what are these?

\footnotetext{
8 I use this terminology for the sake of simplicity and because in many cases the second argument is inanimate.
} 
The referents in question cannot be part of a conjoined RP, despite the potentially confusing use of the preposition with: Hammer and fohn cannot be conjoined, contrary to fohn and Mary or fohn and computer virus. What is in fact being described is a situation where an individual performs an action (e.g. running to a certain location) and the inanimate accompanies the individual as a consequence of being carried or being stuffed in the individual's pocket. The inanimate is simply 'along for the ride' but otherwise uninvolved.

I propose to model this in a similar fashion to RRG's implements: A connective followed by a general predicate is added to the main logical structure. In case of implements, there is a general predicate of usage. I base my approach on Farrell's (2009) treatment of be-with'. Farrell argues in favor of a predicative use of with to account for a wide range of phenomena. Even though I reject much of his analysis, I do adopt the core concept of be-with' (in a modified way). I propose to treat be-with' as a general predicate of accompaniment that occurs in the LS if the arguments in question are nothing more than co-occurrents. That is, they are not coauthors, nor are they under the scope of one another. ${ }^{9}$ Be-with' can also account for languages with so-called with-possessives (Stassen 2009: $54 \mathrm{ff}$.). Thus, for sentences such as the one in (45b), I propose the structure below:

$$
\begin{aligned}
& {\left[\left[\text { do' }^{\prime}\left(\text { John, }\left[\text { run' }^{\prime}(\text { John })\right]\right) \& \text { INGR be-at' }(\text { store, John) }] \wedge\right.\right.} \\
& \text { be-with' }(\text { hammer, John) }]
\end{aligned}
$$

The arguments of the accompaniment predicate can be considered co-occurrents. Such a predicate can also account for a wide range of sentences expressing some form of accompaniment, both literal and figurative. Consider the sentences in (47) and their corresponding logical structures.
a. John is with Mary.
b. be-with' (Mary, John)
c. He's with us. (In the sense of He belongs to our group/unit)
d. be-with' (1PL, 3SG)

9 This is in contrast to Farrell (2009), who, in my view, greatly exaggerates the relevance of predicative with. Also see below. 
e. I'm with you. (In the sense of I am on your side, I share your opinion. Van Valin, p.c.)

f. be-with' (2SG, 1SG)

g. I put the CDs with the DVDs. (Farrell 2009: 181)

h. [do' (1SG, Ø)] CAUSE [BECOME be-with' (DVDs, CDs)]

The sentences in (47c-47f) are figurative in nature, yet clearly metaphorically derived from the more primitive, basic local reading that (47a) exemplifies. This is similar to be-at' expressing possession in languages without a have predicate: Finnish, for instance, does not have a have-verb and thus, one cannot posit a have' predicate in its logical structures. RRG can solve this by positing (in the case of Finnish) be-at' with the possessive reading being a metaphorical extension (cf. Lakoff \& Johnson 1980a $\&$ b). I follow this principle to capture the figurative uses of be-with' in English. Interestingly, in closely related languages like Dutch and German, be-with' has the literal local reading only. For instance, in Dutch, (47c) would have to be expressed with the phrasal verb horen bij (belong to) and (47e) would have to be expressed with the equivalent of agree with (akkoord gaan/zijn met).

This approach can also capture a perfectly possible reading of Francis ran to the hospital with Mary where Mary is not co-author, but rather is unconscious and being transported by Francis. This reading is made explicit in (48).
a. Francis ran to the hospital with his unconscious dog.
b. [[do' (Francis, [run' (Francis)]) \& INGR be-at' (hospital, Francis) $] \wedge$ be-with' (his unconscious dog, Francis)]
c. Marco ran to the hospital with his unconscious daughter.
d. [[do' (Marco, [run' (Marco)]) \& INGR be-at' (hospital, Marco) $] \wedge$ be-with' (his unconscious daughter, Marco)]
e. ${ }^{*}$ Marco and his unconscious daughter ran to the hospital.

It would be difficult to account for (48c) with the standard RRG-approach to comitatives. On the telic quale, daughter would essentially have the 
same properties as Marco. This would predict that example (48e) is grammatical, whereas it is clearly not. The use of be-with' renders this problem moot. It would also be tricky to account for (49) with standard RRG.

*The unconscious construction worker ran to the hospital.

Standard RRG captures selectional restrictions primarily in terms of qualia. The unconscious nature of the referent is what makes this sentence unacceptable. Yet, it would be very difficult to account for this induced feature with qualia. My actionality approach, however, allows for induced features. Introducing unconscious would lower the referent's autonomy to a level that is no longer compatible with the requirements of the argument position in the relevant LS.

The general nature of be-with' does not entail any specific information on the mode of transportation: The dog and the daughter can be carried, drawn in a cart, dragged etc. The only thing the predicate conveys is that during the action described by the first section of the LS, another entity occupies a point in space and time that is almost identical with that of the other. Farrell (2009: 193) points out that not only English has a linguistic expression similar to be with. Portuguese does too, as can be seen in ((50)).

Os omens estão com as mulheres.

DEF men be.PRS.3PL with DEF women

'The men are with the women.' (Farrell 2009: 193, glossing mine)

It can be objected that be-with' only expresses a vague meaning. Yet, languages are full of mechanisms to express the vague and unspecific: Passives can be used as a strategy to make the actor unspecific, partitive constructions are cross-linguistically used to express unspecific amounts of something, ISA can be used to leave the instigator unspecified etc.

Farrell (2009: 196) argues in favor of treating (29a-29b, repeated in $(51 a-51 b))$ as involving different LSs. The latter would feature conjoined arguments, the former would add a be-with' predicate to include Sonia in the with-PP. Even though I also make a case for be-with', I reject Farrell's assumptions regarding the difference between (51a) and (51b), due to the fact that the two referents are co-authors. The simple sentence alternations in (51) would require very different LSs, making it difficult to 
account for the co-authorhood of the two referents. I argue in favor of using be-with' more restrictively: It specifically codes cases where the two referents are not co-authors. In all of my examples of this phenomenon (e.g. (48)), the second referent is only passively involved in the event and cannot be considered co-author.
a. John walked with Sonia.
b. John and Sonia walked.
c. Sonia walked with fohn.
d. Sonia and John walked.

The be-with' predicate is not yet included in contemporary RRG. Including it does not only explain the phenomenon above, but also complements the already existing be-in', be-on' and be-at' predicates in a natural fashion. Furthermore, it is a natural instantiation of the underspecified beLOC' (Farrell 2009: 193). Following Farrell (2009: 201), I propose to define the be-with' predicate as a predicate expressing a general spatio-temporal co-occurrence. This is distinct from location proper. Contrary to Farrell, I restrict the use of be-with' to cases where there is no co-authorhood. This includes potential comitatives ((52)).

(52) a. Jack went to the store without Fill. (Farrell 2009: 196)

b. $\quad$...^ NOT be-with' (Jill, Jack)

Even though I agree with Farrell's treatment of (52), there is still no reason to assume be-with' for all comitatives. If an entity is not present, there cannot be co-authorhood and a representation in terms of conjoined arguments becomes moot. Therefore, recognizing (52b) does not contradict standard RRG's conception of comitatives. By way of conclusion to this section, I recognize a predicative with, contrary to standard RRG (Van Valin 2013: 102).

\subsubsection{False inanimate comitatives}

If with-phrases in inanimate comitatives are not extraposed, a reading of identity becomes possible and even likely, as illustrated in (53). 
(53) a. The woman ran into the store with the book.

b. The woman with the book ran into the store.

c. John ran into the store with the hammer.

d. Fan met de hamer liep de winkel Jan with DEF hammer run\PST.3SG DEF store binnen. into (Dutch)

The book in (53b) is read as a defining feature of the woman. In Dutch, the with-PP can occur in adjacency to proper nouns, yielding an identity reading ((53d)). Fan met de hamer would attribute the hammer to fan in that he often has a hammer with him. I propose to analyze such cases as an underlying possessive RP that obligatorily makes the possessor the head (at least in Dutch and English) to attain the attribute reading. Consider the analysis below (Van Valin \& LaPolla 1997: 189-192, Van Valin 2005: 52).
a. The woman's book
b. have' (woman, book)
c. The woman with the book
d. have' (woman, book)
e. The man with the beard (Farrell 2009: 194)
f. have-as-part' (man, beard)

$(54 a-54 b)$ represent the case where the possessed referent is selected as the head of the phrase, which is expressed by the underlining of book. If the possessor is chosen as head (as in (54d)), the corresponding result is (54c). The attribute reading is only possible with the possessor as the head:

$$
\text { *The woman's book ran into the store. }
$$

Extraposition, such as in the hammer example in (45b), is not possible because it is one single, complex RP. Put differently, extraposition is only a possible strategy if 1 ) there are conjoined RPs (in the case of comitatives) or 2) if there is an underlying be-with' predicate. With the latter, extraposition is obligatory. Otherwise, the attributive reading is triggered as (53b) showed. Bear in mind that this holds for common nouns as the actor in English. Proper nouns tend to complicate matters further. Following 
Farrell (2009: 196), the absence of a property can be accounted for by including NOT.
a. The man without a beard
b. NOT have-as-part' (man, beard)

\subsection{Proper parts as instruments}

Apart from the typical instrument referents such as knife, cannon, brush and the like, proper parts of an entity (such as body parts) can also be used as instruments. Luraghi (1995: 265) points out that humans can and will carry out activities with tools, including their own body parts. Some case grammarians have entertained the idea of a so-called 'body part instrument' as a case for almost every occurrence of a body part in an utterance (Bibović 1976: 313). From an RRG point of view, proper parts functioning as instruments must meet the very same criteria that more prototypical instruments meet. That is to say, the proper part in question must be causally embedded. A sentence like the one in (57a) does not feature a body part instrument but a simple undergoer that happens to be a body part. This verb patterns like a semelfactive and therefore correlates to the LS in (57b).

(57) a. Ernesto nodded his head. (adapted from Bibović 1976: 314)

b. SEML do' (Ernesto, [nod' (Ernesto, his head)])

However, consider sentences like (58) with their Dutch equivalents.

(58) a. He untied the knot with his teeth. (Nilsen 1973: 130)

b. I bit him with my false teeth. (Lyons 1968: 422)

c. Hij deed de knoop los met zijn 3SG do\PST.3SG DEF knot loose with POSS.3SG tand-en. tooth-PL

d. Ik beet hem met mijn valse tand-en. 1SG bite $\backslash$ PST.1SG him with POSS.1SG false tooth-PL 
Superficially, the relevant arguments seem to be instruments. This has to be put to the test using the appropriate paraphrase.

(59) a. ??He acted on his teeth, causing them to untie the knot.

b. ??I acted on my false teeth, causing them to bite him.

The paraphrase test identifies teeth/tanden as something other than an instrument. The test shows that there is no causal embedding. This is not only the case for human body parts as instruments but also for proper parts of other referents. Consider:

(60) a. The digger dug a hole with its scoop.

b. ??The digger acted on the scoop, causing it to dig a hole.

c. The algorithm crippled the mainframe with its coding.

d. ??The algorithm acted on the coding, causing it to the cripple the mainframe.

e. The computer virus crippled the server with spam-mails.

f. The computer virus acted on the spam-mails, causing them to cripple the server.

The paraphrase test reveals that proper parts of entities do not have the same status that 'normal' instruments have. Conceptually, this makes sense: A person does not act on the teeth, causing them to do something. Rather, body parts and proper parts are seen as extensions of the instigator rather than as separate entities. In (60c) and (60d), coding is what makes up an algorithm, rather than a separate entity that is impinged upon. Note that sentences like (60e-60f) are much more acceptable: A computer virus can use independent entities (such as files on the hard drive or spam-mails) to wreak havoc. Likewise, the digger does not really impinge on the scoop. Even though (60a) and (60c) can be expressed with a with-PP, they become more acceptable if by means of is used instead. Normal instruments normally disprefer such a linking, even though it is not entirely ruled out. Consider (61c-61d) and their Dutch and German equivalents in (61e-61f) and $(61 \mathrm{~g}-61 \mathrm{~h})$, respectively. The choice of by means of as marker primarily holds for inanimate proper parts ((61a-61b)), but much less for body parts of animates $((61 \mathrm{i}-61 \mathrm{j}))$. 
(61) a. The digger dug a hole by means of its scoop.

b. The algorithm crippled the mainframe by means of its coding.

c. ?The lumberjack cut down the tree by means of an axe.

d. ?fohn cut the cake by means of a knife.

e. ?De houthakker vel-de de boom

DEF lumberjack cut down-PST.3SG DEF tree door middel van een bijl.

through means of INDEF axe (Dutch)

f. ?fan sneed de cake in stukk-en

Jan cut $\backslash$ PST.3SG DEF cake in piece-PL

door middel van een mes.

through means of INDEF knife

g. ?Der Holzfäller fäll-te den Baum

DEF lumberjack cut down-PST.3SG DEF tree

mittels eine-r Axt.

by means of INDEF-GEN axe (German)

h. ?fan schnitt den Kuchen in Stück-e

Jan cut|PST.3SG DEF cake in piece-PL

mittels eine-s Messer-s.

by means of INDEF-GEN knife-GEN

i. $\quad$ ?/*He untied the knot by means of his teeth.

j. $\quad$ ?/*The lion killed the gazelle by means of its teeth.

Parallel to English, door middel van and mittels are the more marked linking options. In addition, German mittels was rated by an informant as written language as opposed to spoken language. However, even within written language, mittels was rated as better with proper parts than with true instruments. It seems then that there is a cross-linguistic preference for a different marker if proper parts of inanimates are concerned. In case of independent entities and proper parts of animates, with $/ \mathrm{mit} / \mathrm{met}$ are preferred. Note that these are only preferences rather than absolute rules. Having established this, the question remains what proper parts are, semantically speaking. As they fail the causal paraphrase, I propose to treat 
them as implements, as entities that help to cause something (cf. Koenig et al. 2008), but not cause something. The teeth arguably increase the chances of untying the knot, but they are not a causer. The larger entity that they are a part of is the true causer, as it passes the causal paraphrase. Therefore, I propose to incorporate proper parts as normal implements. The verbs untie and bite test as a causative accomplishment and an activity, respectively. As teeth is not an effector in the untie example, it has to be represented as an implement. The LSs in $(62 \mathrm{a}-62 \mathrm{~d})$ correlate with the examples above:

$$
\begin{aligned}
& \text { a. } \quad\left[[ \text { do } ^ { \prime } ( 3 S G , \varnothing ) ] \text { CAUSE } [ \text { BECOME untied' } ( \text { knot } ) ] \wedge \left[\text { do }^{\prime}\right.\right. \\
& \text { (3SG, [use' (3SG, teeth)])]] } \\
& \text { b. [do' (1SG, [bite' }(1 S G, 3 S G) \wedge \text { use }^{\prime}(1 S G, \text { my false teeth)])] } \\
& \text { c. }\left[[ \text { do' } ^ { \prime } ( 3 S G , \varnothing ) ] \text { CAUSE } [ \text { BECOME untied' (knoop) } ] \wedge \left[\text { do' }^{\prime}\right.\right. \\
& \text { (3SG, [use' (3SG, tanden)])]] } \\
& \text { d. [do' }\left(1 S G \text {, [bite' }(1 S G, 3 S G) \wedge \text { use' }^{\prime}(1 S G \text {, mijn valse }\right. \\
& \text { tanden)])] }
\end{aligned}
$$

The main difference to normal implements is conceptual in nature: Proper parts are somewhat different than concrete objects like stick or knife, because the latter are independent entities.

\subsection{Potential instruments, implements \& comitatives}

Farrell (2009) argues in favor of using be-with' to account for all comitatives (amongst others). Although this completely ignores co-authorhood, I do believe a similar approach can account for potential instances of instruments, implements and comitatives. Potential refers to the absence of a referent from a certain state of affairs and the fact that the referent could potentially be used or involved in the action. This absence is largely conceptual, however, as the referents are still expressed in the morphosyntax. Following RRG's Completeness Constraint, these referents must be present in the LS. Comitatives are primarily defined over positional equivalence. If there is no positional equivalence, then positing co-authorhood 
and an LS with conjoined arguments would be paradoxical $((63 \mathrm{c}))$. The typical comitative alternation in (63b) is inadmissible because it is not truth-conditionally equivalent to (63a). An LS where the second argument is left unspecified $((63 \mathrm{~d}))$ is problematic for two reasons: 1$)$ it is unclear what it would link to and 2) it does not account for the occurrence of Elena thereby violating the completeness constraint. Following Farrell (2009: 196), I propose to capture without as NOT be-with'. This LS is given in (63e).

a. Caroline ran to the store without Elena.

b. "Elena ran to the store without Caroline.

c. $\quad$ ? ${ }^{*}\left[\left[\mathbf{d o}^{\prime}(\right.\right.$ Caroline $\wedge \neg$ Elena, $[$ run' $($ Caroline $\wedge \neg$ Elena) $]) \&$ INGR be-at' (store, Caroline $\wedge \neg$ Elena) $]$

d. $\quad *\left[\left[\right.\right.$ do' $^{\prime}($ Caroline $\wedge \emptyset,[$ run' $($ Caroline $\wedge \varnothing)]) \&$ INGR be-at' (store, Caroline $\wedge \varnothing)]$

e. $\quad\left[\left[\mathbf{d o}^{\prime}\right.\right.$ (Caroline, [run' (Caroline)]) \& INGR be-at' (store, Caroline) $] \wedge$ NOT be-with' (Elena, Caroline)]

Apart from potential comitatives, potential instruments and implements also exist. McKercher (2003: 173) gives an example of an implement where it is in fact, absent ((64a)).
a. Kim ate pizza without a fork.
b. Kim at pizza zonder vork.
Kim eat $\backslash$ PST.3SG pizza without fork (Dutch, own data)
c. Abdul ate soup without a spoon.
d. Abdul at soep zonder lepel.
Abdul eat $\backslash$ PST.3SG soup without spoon

To satisfy the completeness constraint, spoon must somehow be present in the LS. Similar to NOT be-with', I propose to use a negated use-predicate. The LSs for (64a-64d) are given in (65). 

a. $\quad$ do' $^{\prime}\left(\right.$ Kim, $\left[\right.$ eat' $^{\prime}($ Kim, pizza $) \wedge$ NOT use' $($ Kim, fork $\left.\left.)\right]\right)$
b. do' $\left(\right.$ Kim, $\left[\right.$ eat' $^{\prime}($ Kim, pizza $) \wedge$ NOT use' $($ Kim, vork $\left.\left.)\right]\right)$
c. do' (Abdul, [eat' $($ Abdul, soup) $\wedge$ NOT use' $($ Abdul, spoon)])
d. do' (Abdul, [eat' $($ Abdul, soep) $\wedge$ NOT use' $($ Abdul, lepel)])

Not only comitatives and implements, but also instruments can be 'potential'. Consider the examples below:

(66) a. Mara destroyed the barn with a wrecking ball.

b. Mara destroyed the barn without a wrecking ball.

c. Sonia melted the ice with a hair dryer.

d. Sonia melted the ice without a hair dryer.

e. The lumberjack cut down the tree with a chainsaw.

f. The lumberjack cut down the tree without a chainsaw.

Here, too, the potential instruments need to be accounted for in the LS. Simply adding a $\neg$ sign or including NOT results in a paradox again. Consider such LSs in (67).


CAUSE [BECOME destroyed' (barn)]]

b. $\quad$ * $\left[\right.$ do' $^{\prime}$ (Sonia, Ø)] CAUSE $\left[\left[\mathbf{d o}^{\prime}(\neg\right.\right.$ hair dryer, $\left.\varnothing)\right]$ CAUSE [BECOME melted' (ice)]]

c. $\quad$ *[do' (lumberjack, Ø)] CAUSE [[do' ( $\neg$ chainsaw, Ø)] CAUSE [BECOME cut down' (tree)]]

d. * * [do' (Mara, Ø)] CAUSE [[NOT do' (wrecking ball, Ø)] CAUSE [BECOME destroyed' (barn)]]

e. $\quad$ * $[$ do' (Sonia, Ø)] CAUSE NOT [[do' (hair dryer, Ø)] CAUSE [BECOME melted' (ice)]]

f. $\quad$ * $\left[\right.$ do' $^{\prime}($ Sonia, $\left.\varnothing)\right]$ NOT CAUSE $\left[\left[\mathbf{d o}^{\prime}\right.\right.$ (hair dryer, Ø)] CAUSE [BECOME melted' (ice)]]

g. ${ }^{*}$ Mara did not act on the wrecking ball, causing it to destroy the barn.

h. $\quad$ *Mara acted on nothing, causing it to destroy the barn. 
i. $\quad{ }^{*}$ Sonia did not act on the hair dryer, causing it to melt the ice.

g. $\quad$ "Sonia acted on nothing, causing it to melt the ice.

j. $\quad$ *The lumberjack did not act on the chainsaw causing it cut down the tree.

k. $\quad$ *The lumberjack acted on nothing, causing it to cut down the tree.

The LSs in (67a-67f) cannot be correct, as the causal paraphrases in $(67 \mathrm{~g}-$ $67 \mathrm{k})$ produce utterly bizarre results. The paraphrases above show that there can be no causal embedding. Yet, the potential instrument must be accounted for in the LS in order to satisfy the completeness constraint. Recall that instruments are only instruments if an implement is causally embedded. The examples in (65) illustrated that negating an implement is unproblematic. I propose to use the same approach for potential instruments. If an implement is not causally embedded, it is not an instrument. If the implement is not even manipulated at all, there certainly cannot be any kind of causal embedding. I therefore propose the LSs in (68):
a. $\quad\left[\left[\right.\right.$ do' $^{\prime}($ Mara,, $\left.)\right]$ CAUSE [BECOME destroyed' (barn) $] \wedge$ [do' (3SG, [NOT use' (Mara, wrecking ball)])]]
b. $\quad\left[\left[\right.\right.$ do' $^{\prime}$ (Sonia, Ø) $]$ CAUSE $[$ BECOME melted' (ice) $] \wedge\left[\right.$ do' $^{\prime}$ (3SG, [NOT use' (Sonia, hairdryer)])]]
c. [[do' (lumberjack, Ø)] CAUSE [BECOME cut down' $($ tree) $] \wedge$ [do' (3SG, [NOT use' (lumberjack, chainsaw)])]]

In this section, I have adopted Farrell's be-with' approach to a modest degree. While I also treat potential comitatives with the predicate's negated version, I reject Farrell's proposal to use be-with' for all comitatives. Contrary to Farrell, I only use be-with' for strictly co-occurrent referents. 


\subsection{Problematic cases of instruments}

A 'problematic case' I wish to address was introduced earlier in this chapter. Farrell (2009: 189-190) provides an example of a causative accomplishment that features an implement. This example, together with Farrell's proposed LS are given in (69a) and (69b), respectively.

(69) a. The boy put together the bike with a manual.

b. [do' (boy, Ø)] CAUSE [BECOME together' (bike) $\wedge$ use' (boy, manual)]

c. $\quad$ "The boy acted on the manual, causing it to put together the bike.

d. $\quad$ *The boy caused the manual to be used.

e. The boy caused the bike to be put together/assembled.

Using the causative paraphrase in (69c) shows that the with-PP is an implement and not an instrument. Farrell's proposed LS, however, is problematic. The way the LS in (69b) is written, the use of the manual is part of the caused event. This is wrong, as the contrast in acceptability of paraphrases in (69d) and (69e) shows. Rather, the manual is a tool that modifies the whole LS: The most likely interpretation for (69a) is that the boy assembled the bike while continuously using a manual. Therefore, it can only relate to the LS in (70a). The LS in (70b) implies that the boy's use of the manual caused the coming about of the event. If the context in (70c) is present, then the LS in (70b) is possible. The distinction between the two readings relates to the placement of the use-predicate in the LS.

(70) a. $\left[\left[\left[\right.\right.\right.$ do' $^{\prime}($ boy, Ø) $]$ CAUSE [BECOME together' (bike) $\left.]\right] \wedge$ [do' (boy, [use' (boy, manual)]]]

b. [do' (boy, [use' (boy, manual)])] CAUSE [BECOME together' (bike)]

c. After having read the manual, the boy put together the bike. 


\subsection{Conclusion}

In this chapter, I explored the semantics of several concepts or phenomena that are superficially related to the typical instruments. Several varieties of comitative were discussed, revealing that the phenomenon is much wider than it is often assumed in the literature. Even though the most prototypical comitative is of the 'actor'-variety, undergoer and NMR-varieties also exist. Although there are some differences between them, they all share a crucial feature which I have called positional equivalence. That is, the two arguments in question must be able to occupy the same positions in the LS. For the actor-comitatives, the actionality levels of the argument's referents must be similar. Each of the arguments must be able to function in the relevant argument position in the LS and this depends on whether the actionality requirements of the slot are met. Whether or not it is possible to alternatively code one of the arguments varies. In the case of actor-comitatives, both arguments require a level of actionality that is almost identical. If the levels are too distinct, then alternatively coding the lower-ranking argument (in terms of the actionality level) would result in an instrument reading and thus link back to an instrument-LS.

Apart from comitatives, human referents in the typical instrument-effector position were also explored. I argued in favor of treating these as causees and proposed to include them as a distinct effector subtype. By contrast, pseudo-agents are not recognized as an effector subtype as they constitute a specific class of referent rather than a distinct reading of the effector role. That is, they can be conceptualized as instruments or instigators. It is also possible for causees to take instruments themselves. In this case, there is a very strong tendency for the causee to be higher in the LS, even though there are exceptions to this. I have formalized this strong tendency as the Relative Power Principle, which can be seen as a governing principle for causees and instruments when they occur in the same LS.

I also provided an updated version of predicative with (be-with') to account for the expression of general spatio-temporal co-occurrence of two referents. This approach can account for sentences where a referent is not wielded by another and those where it cannot be co-author of a state 
of affairs. Typically, this includes cases where one referent is passively spatio-temporally present throughout the event as is hammer in fohn ran to the store with his hammer. Be-with' can also be used for figurative belonging to a group or unit. Potential instruments and implements were introduced as the expression of a non-use. Stating that an action was performed without a tool expresses that it was not used. However, as potentials occur in the morphosyntax, they must be present in the semantic representation so as not to violate the completeness constraint. To account for such cases, I proposed treating them as the negated versions of implements (i.e. NOT use'). Potential comitatives refer to non-accompaniment. It was illustrated that negating a normal comitative is overly simplistic and untenable. I therefore argued in favor of a predicative without (i.e. NOT be-with').

Properties of individuals are often expressed with the preposition with, as in, for example, the woman with the book. To capture these, I adopted RRG's approach to the structure of RPs. 